\title{
Exogenous melatonin prevents type 1 diabetes mellitus-induced bone loss, probably by inhibiting senescence
}

\author{
Z. Gong $^{1} \cdot$ W. Da ${ }^{1} \cdot$ Y. Tian ${ }^{1} \cdot$ R. Zhao ${ }^{1} \cdot$ S. Qiu ${ }^{1} \cdot$ Q. Wu ${ }^{1} \cdot$ K. Wen ${ }^{1} \cdot$ L. Shen $^{1} \cdot$ R. Zhou ${ }^{1} \cdot$ L. Tao $^{1} \cdot$ Y. Zhu $^{1}$
}

Received: 30 October 2020 / Accepted: 30 June 2021 / Published online: 14 September 2021

(C) The Author(s) 2021

\begin{abstract}
Summary Exogenous melatonin inhibited the senescence of preosteoblast cells in type 1 diabetic (T1D) mice and those cultured in high glucose $(\mathrm{HG})$ by multiple regulations. Exogenous melatonin had a protective effect on diabetic osteoporosis, which may depend on the inhibition of senescence.

Introduction Senescence is thought to play an important role in the pathophysiological mechanisms underlying diabetic bone loss. Increasing evidence has shown that melatonin exerts anti-senescence effects. In this study, we investigated whether melatonin can inhibit senescence and prevent diabetic bone loss.

Methods C57BL/6 mice received a single intraperitoneal injection of $160 \mathrm{mg} / \mathrm{kg}$ streptozotocin, followed by the oral administration of melatonin or vehicle for 2 months. Then, tissues were harvested and subsequently examined. MC3T3-E1 cells were cultured under HG conditions for 7 days and then treated with melatonin or not for $24 \mathrm{~h}$. Sirt1-specific siRNAs and MT1- or MT2-specific shRNA plasmids were transfected into MC3T3-E1 cells for mechanistic study.

Results The total protein extracted from mouse femurs revealed that melatonin prevented senescence in T1D mice. The microCT results indicated that melatonin prevented bone loss in T1D mice. Cellular experiments indicated that melatonin administration prevented HG-induced senescence, whereas knockdown of the melatonin receptors MT1 or MT2 abolished these effects. Sirt1 expression was upregulated by melatonin administration but significantly reduced after MT1 or MT2 was knocked down. Knockdown of Sirtl blocked the anti-senescence effects of melatonin. Additionally, melatonin promoted the expression of CDK2, CDK4, and CyclinD1, while knockdown of MT1 or MT2 abolished these effects. Furthermore, melatonin increased the expression of the polycomb repressive complex (PRC), but knockdown of MT1 or MT2 abolished these effects. Furthermore, melatonin increased the protein levels of Sirt1, PRC1/2 complex-, and cell cycle-related proteins.

Conclusion This work shows that melatonin protects against T1D-induced bone loss, probably by inhibiting senescence. Targeting senescence in the investigation of diabetic osteoporosis may lead to novel discoveries.
\end{abstract}

Keywords High glucose $\cdot$ Melatonin $\cdot$ Osteoporosis $\cdot$ Senescence $\cdot$ Type 1 diabetes

\section{Introduction}

Osteoporosis is an important factor affecting global morbidity and mortality. Currently, OS is thought to be a complication of type 1 diabetes (T1D). This relationship is further confirmed

Zunlei Gong and Wacili Da are the first authors.

L. Tao

taolindr@163.com

Y. Zhu

zhuyuedr@163.com

1 Department of Orthopedics, The First Hospital of China Medical University, Shenyang 110001, China by the decreased bone mineral density and increased risk of fracture in patients with T1D [1]. As an independent risk factor for osteoporosis, T1D has attracted people's attention in recent years $[2,3]$. Bone mineral density is decreased by 22 to $37 \%$ in patients with T1D [4], and this effect is more obvious for patients with long-term T1D [5]. Long-term hyperglycemia and the acclimation of advanced glycation end products lead to osteoporosis and fracture [6]. Morbidity and mortality rates are more serious in T1D patients than in nondiabetic patients. Therefore, anti-osteoporosis treatment is necessary, and the treatment of diabetic osteoporosis requires further research.

Senescence has been recently shown to play an important role in the pathophysiological mechanisms of diabetic 
osteoporosis. Diabetes promotes senescence, reduces the turnover of bone and blood vessels, and then exacerbates changes in the bones of older mice [7]. Compared with that in healthy controls, the proportion of senescent cells among MSCs in type 1 diabetes patients increased, as did the proportion of senescent cells among MSCs cultured under high-glucose (HG) conditions [8]. Umbilical cord mesenchymal stem cells from gestational diabetes mellitus patients showed obvious premature cellular senescence accompanied by significantly decreased osteogenic potential [9].

Increasing evidence has shown that melatonin exerts antisenescence effects by preventing oxidative stress, inflammation, and mitochondrial dysfunction $[10,11]$. However, whether melatonin alleviates T1D- or HG- induced senescence has not been reported. With increasing age, a decrease in melatonin occurs, and this decrease is considered to be the key factor in osteoporosis [12]. Additionally, there is an agerelated reduction in the mRNA levels of the melatonin receptors MT1 and MT2 in mice [11]. Pinealectomy in sheep increased trabecular separation but reduced thickness, leading to reduced bone mineral density and osteoporosis [13]. The BMD of the femoral neck and spine in postmenopausal women with osteopenia increased in a dose-dependent manner after 1 year of melatonin treatment [14]. However, whether melatonin can prevent diabetic osteoporosis has not been reported.

Therefore, we proposed the hypothesis that melatonin administration may prevent HG- and T1D-induced senescence, and the protective effects of melatonin against senescence may play a pivotal role in preventing osteoporosis. To test our hypothesis, we established a C57BL/6 mouse model of T1D and an HG-treated MC3T3-E1 cell model.

\section{Materials and methods}

\section{Cell culture}

MC3T3-E1 cells, which are preosteoblast cells with osteoblast differentiation ability, were used for the in vitro experiments and obtained from the Shanghai Cell Bank of the Chinese Academy of Sciences. The MC3T3-E1 cells were cultured in $\alpha$-MEM medium containing $10 \%$ fetal bovine serum and $1 \%$ penicillin and streptomycin at $37^{\circ} \mathrm{C}$. When the cell density reached $80 \%$, the cells were digested with $0.25 \%$ trypsin EDTA solution for the next experiment. The culture medium was changed every 3 days. The MC3T3-E1 cells were cultured with $\mathrm{HG}$ medium for 7 days and then treated with 1 $\mu \mathrm{mol} / 1$ melatonin (M5250, Sigma-Aldrich, America) or not for $48 \mathrm{~h}$ before being harvested for senescence-associated $\beta$ galactosidase staining, DCFH-DA analysis, immunofluorescence analysis, quantitative real-time PCR (RT-qPCR) analysis, and cell cycle analysis.

\section{Cell Counting Kit-8 (CCK-8) assay}

CCK-8 kit assay (CK04, Dojindo, Japan) was performed according to the manufacturer's instructions after MC3T3-E1 cells were cultured with $\alpha$-MEM medium containing various concentrations of glucose $(5 \mathrm{mmol} / \mathrm{l}, 10 \mathrm{mmol} / \mathrm{l}, 15 \mathrm{mmol} / \mathrm{l}$, $20 \mathrm{mmol} / \mathrm{l}$, and $25 \mathrm{mmol} / \mathrm{l}$ ) for 7 days. The cells were then treated with melatonin $(0 \mathrm{nmol} / 1,1 \mathrm{nmol} / 1,10 \mathrm{nmol} / \mathrm{l}, 100$ $\mathrm{nmol} / \mathrm{l}, 1 \mu \mathrm{mol} / \mathrm{l}, 10 \mu \mathrm{mol} / 1$, and $100 \mu \mathrm{mol} / \mathrm{l}$; SigmaAldrich, America) for $48 \mathrm{~h}$ before being harvested. The absorbance of each well was measured at $450 \mathrm{~nm}$ with an enzymelinked immunosorbent instrument after incubation at $37^{\circ} \mathrm{C}$ for $1 \mathrm{~h}$.

\section{Senescence-associated $\beta$ galactosidase staining (SA- $\beta$ - Gal staining)}

As a canonical marker of cell senescence, SA- $\beta$-Gal staining was used to identify senescent cells. MC3T3-E1 cells were washed with PBS 3 times, fixed with $1 \mathrm{X}$ fixation solution for $15 \mathrm{~min}$, and incubated with dimethylformamide (12767, CST, America) diluted 1X $\beta$-galactosidase staining solution (9860, $20 \mathrm{mg} / \mathrm{ml}, \mathrm{pH} 6.0$, CST, America) overnight with parafilm sealed in a $37{ }^{\circ} \mathrm{C}$ dry incubator without $\mathrm{CO}_{2}$. Images of each group were captured with an Olympus light microscope (Olympus, Tokyo, Japan).

\section{DCFH-DA analysis}

DCFH-DA analysis was used to evaluate the cellular ROS production. MC3T3-E1 cells were washed with PBS 3 times and incubated with $10 \mu \mathrm{mol} / 1 \mathrm{PBS}$-diluted DCFH-DA (D6883, Sigma-Aldrich, America) for $30 \mathrm{~min}$ at $37^{\circ} \mathrm{C}$ in dark field. Subsequently, the cells were washed 3 times with PBS. Fluorescence images were captured with an Olympus inverted microscope (Olympus, Tokyo, Japan).

\section{Immunofluorescence analysis}

$\gamma$-H2AX staining was used to identify cellular DNA damage. MC3T3-E1 cells were washed with cold PBS 3 times, fixed with $4 \%$ paraformaldehyde for $1 \mathrm{~h}$, and incubated with primary antibody against $\gamma$-H2AX (ab81299, 1:1000, Abcam, America) overnight at $4{ }^{\circ} \mathrm{C}$. The cells were washed with cold PBS 3 times and coincubated with secondary antibody (Rs3211, 1:1000, ImmunoWay, China) and phalloidin (ab176757, 1:1000, Abcam, America) at room temperature for $1 \mathrm{~h}$. After washing with cold PBS 3 times, the cells were stained with DAPI $(4083,0.1 \mu \mathrm{g} / \mathrm{ml}, \mathrm{CST}$, America) for 5 min. After washing with cold PBS 3 times, images were captured with an Olympus inverted microscope (Olympus, Tokyo, Japan). 


\section{Quantitative real-time PCR analysis}

Total RNA was isolated with TRIzol reagent (15596026, Thermo Fisher, America) and an RNA purification kit (12183555, Thermo Fisher, America). cDNA was synthesized with the PrimeScript ${ }^{\mathrm{TM}}$ RT Reagent Kit (RR037A, TaKaRa, Japan). RT-qPCR was performed with Fast Real-time PCR System (Roche 480, Switzerland) using a TB Green $®$ Premix Ex Taq ${ }^{\mathrm{TM}}$ Kit (RR820A, TaKaRa, Japan). The following mRNAs that related to the induction of senescence were selected: p16 (ID: 12578), p21 (ID: 12575), IL-1 $\beta$ (ID: 16176), and TNF- $\alpha$ (ID: 21926). The following mRNAs that related to the regulation of senescence were selected: Sirt1 (ID: 93759), CDK2 (ID: 12566), CDK4 (ID: 12567), cyclinD1 (ID: 12443), Bmi1 (ID: 12151), Rnf2 (ID: 19821), Suz12 (ID: 52615), and Ezh2 (ID: 14056). The following mRNAs related to osteogenesis were selected: Runx2 (ID: 12393) and Osterix (ID: 170574). The relative gene expression was normalized to $\beta$-actin. Details of the primers (Thermo Fisher, America) are shown in Supplementary Table 1.

\section{Animal experiments-animal group}

All the animal experiments were approved by the Ethics Committee of the First Affiliated Hospital of China Medical University. Thirty-six 8-week-old C57BL/6 male mice from China Medical University were given free access to water and food and were housed under a 12-h light/dark cycle and constant temperature. Streptozotocin (V900890, Sigma-Aldrich,

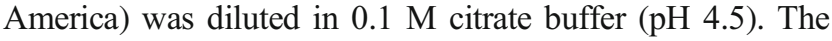
mice were treated intraperitoneally with vehicle or streptozotocin $(160 \mathrm{mg} / \mathrm{kg})$ in a single dose. One week after STZ injection, an intraperitoneal glucose tolerance test (IPGTT) was performed after overnight fasting and intraperitoneal injection of $1 \mathrm{~g} / \mathrm{kg}$ glucose. Blood samples were collected from the tail vein at $0,10,20,30,60,90$, and $120 \mathrm{~min}$. Blood glucose and insulin were measured by a OneTouch glucometer analyzer (Roche, Switzerland) and mouse insulin kit (Millipore, Germany), respectively. Once the fasting blood glucose concentration exceeded $200 \mathrm{mg} / \mathrm{dl}$ for more than 1 week, the mice were considered to be diabetic. The mice that did not conform to the criteria were excluded. The mice were treated with oral administration of vehicle or melatonin (M5250, $60 \mathrm{mg} / \mathrm{kg} /$ day, Sigma-Aldrich, America) for 2 months. Then, the bilateral femurs were harvested for micro$\mathrm{CT}$ analysis and protein extraction after the mice were asphyxiated by $\mathrm{CO}_{2}$.

\section{Western blot analysis}

Femurs were harvested, and the muscle and connective tissues were moved. The femurs were cut in the middle with sterilized scissors. The two parts of the femurs were placed in a centrifuge tube with the cut edges toward the bottom. Bone marrow was removed by high-speed centrifugation and PBS washing. Total femur samples containing the metaphysis and diaphysis were quickly frozen in liquid nitrogen and then crushed into small pieces with sterilized scissors. Following the manufacturer's instructions of the Invent kit (SA-02-BT, America), the total proteins were extracted from the bone samples. Proteins were extracted from MC3T3-E1 cells using denaturing protein solution (WA-009, Invent, America) supplemented with a mixture of protease and phosphatase inhibitors (Beyotime, China). Protein separation was carried out under reducing conditions on a $6-12 \%$ Tris-acetate gel (Beyotime, China). The proteins were then transferred to the nitrocellulose membranes. The membranes were blocked in a buffer containing 5\% milk for $1 \mathrm{~h}$, and then incubated in 5\% BSA buffer containing primary antibody at $4{ }^{\circ} \mathrm{C}$ overnight. After washing in TBST, the membranes were incubated with secondary antibody at room temperature for $1 \mathrm{~h}$. The signals were detected after using ultrasensitive ECL luminescent solution (Proteintech, China). The following proteins that related to senescence identification and senescence modulation were selected. Rabbit antibody p16 (ab51243, 1:1000, Abcam, America), $\gamma$-H2AX (Ab81299, 1:5000, Abcam, America), p21 (ab188224, 1:1000, Abcam, America), p53 (ab33889, 1:1000, Abcam, America), ATM (ab199726, 1:2000, Abcam, America), MT1 (ab203038, 1:100, Abcam, America), MT2 (ab203346, 1:100, Abcam, America), Sirt1 (ab189494, 1:1000, Abcam, America), CDK2 (Ab32147, 1:1000, Abcam, America), CDK4 (ab108357, 1:1000, Abcam, America), cyclinD1 (ab40754, 1:1000, Abcam, America), Bmil (ab155069, $1 \mu \mathrm{g} / \mathrm{ml}$, Abcam, America), Rnf2 (ab181140, 1:1000, Abcam, America), Ezh2 (ab191080, 1:500, Abcam, America), Suz12 (ab175187, 1:1000, Abcam, America), Bcl2 (ab182858, 1:2000, Abcam, America), and Runx2 (Ab236639, 1:1000, Abcam, America) were used to detect relative proteins. Mouse anti- $\beta$-actin (66009-1-Ig, Proteintech, China) was used as a load control. Goat anti-mouse (SA00001-1, Proteintech, China) and goat anti-rabbit (SA00001-2, Proteintech, China) antibodies were used as secondary antibodies. Details about the antibodies are shown in Supplementary Table 2.

\section{Cell cycle analysis}

MC3T3-E1 cells were digested and resuspended and then fixed with $1 \mathrm{ml}$ cold $70 \%$ ethanol at $-20{ }^{\circ} \mathrm{C}$ overnight. After PBS washing, $50 \mu \mathrm{g} / \mathrm{ml}$ PI $(4087,50 \mu \mathrm{g} / \mathrm{ml}$, CST, America) staining solution containing RNase A was added. Red fluorescence was detected at an excitation wavelength of $488 \mathrm{~nm}$ by flow cytometry (Beckman, America) after $30 \mathrm{~min}$ of incubation in a water bath at $37^{\circ} \mathrm{C}$, and at least 10,000 cells were counted for each sample. The results were analyzed by Flow Jo 10 (BD, America) software. 

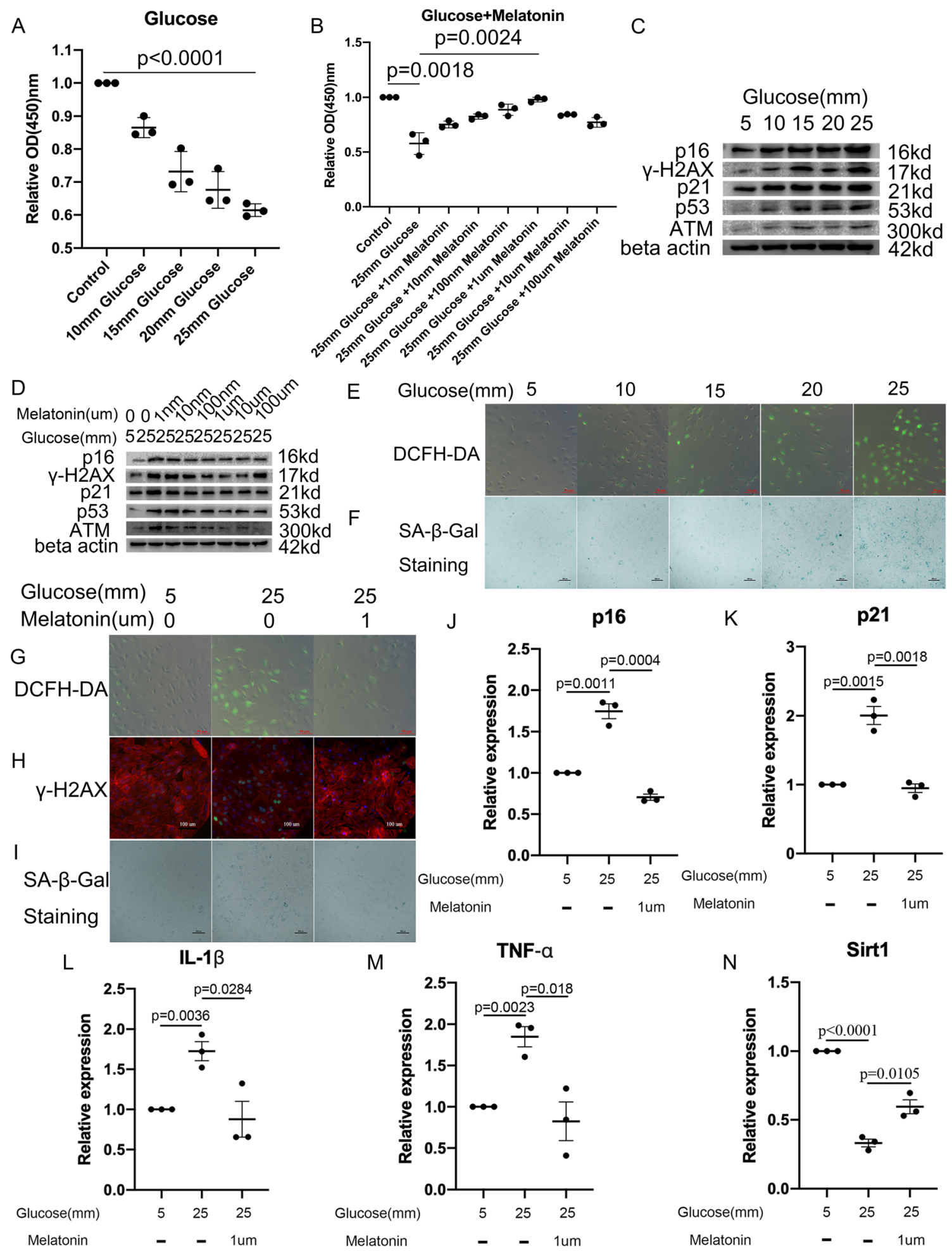

\section{Gene transfection}

MC3T3-E1 cells were cultured to $80 \%$ confluence under HG conditions for 7 days and then were treated with medium without FBS or antibiotic reagents for $6 \mathrm{~h}$. Sirt1-specific
SMART pool siRNAs (100 nmol/l, RiboBio, China) or MT1- or MT2-specific shRNA plasmids (GenePharma, China) were mixed with Lipofectamine 2000 reagent (11668027, Thermo Fisher, America) and then incubated for $15 \mathrm{~min}$ at room temperature. The cells were cultured with the 
Fig. 1 Melatonin alleviated HG-induced senescence of MC3T3-E1 cells. A, C, E, F MC3T3-E1 cells were cultured with different concentrations of glucose medium ( $5 \mathrm{~mm}, 10 \mathrm{~mm}, 15 \mathrm{~mm}, 20 \mathrm{~mm}, 25 \mathrm{~mm}$ ) for 7 days. B, D MC3T3-E1 cells were cultured with normal or HG medium for 7 days followed by different concentrations of melatonin $(0,1 \mathrm{~nm}, 10 \mathrm{~nm}, 100$ $\mathrm{nm}, 1 \mu \mathrm{m}, 10 \mu \mathrm{m}, 100 \mu \mathrm{m})$ for $48 \mathrm{~h}$. A, B CCK8 assay was delivered to measure the proliferation of MC3T3-E1 cells under different conditions. C, D Total proteins were extracted from MC3T3-E1 cells and blotted with anti-p16, anti-p21, anti-p53, anti- $\gamma$-H2AX, anti-ATM, and antibeta actin antibodies. E, F MC3T3-E1 cells were stained with DCFHDA (green) and SA- $\beta$-Gal (blue). Scale bars $=50 \mu \mathrm{m}, 200$ px. G-N MC3T3-E1 cells were cultured with HG medium for 7 days followed by $1 \mu \mathrm{m}$ melatonin for $48 \mathrm{~h}$. G-I MC3T3-E1 cells were stained with DCFH-DA (green), $\gamma$-H2AX (red), and SA- $\beta$-Gal (blue). Scale bars = $50 \mu \mathrm{m}, 100 \mu \mathrm{m}, 200 \mathrm{px}$. $\mathbf{J}-\mathbf{N}$ The relative mRNA expression levels of $\mathrm{p} 16, \mathrm{p} 21, \mathrm{IL}-1 \beta, \mathrm{TNF}-\alpha$, and Sirt1 were normalized to beta actin were recorded. Data of $\mathbf{A}, \mathbf{B}$, and $\mathbf{J}-\mathbf{N}$ were presented with mean $\pm \mathrm{SEM}$ and analyzed by Graph Pad Prism 8.2.0 (San Diego, CA, USA) with twotailed unpaired Student's t test. Statistical significance was determined as $\mathrm{p}<0.05$

conditioned medium for $6 \mathrm{~h}$ at $37^{\circ} \mathrm{C}$. The transfected cells were cultured with or without $1 \mu \mathrm{mol} / 1$ melatonin for $48 \mathrm{~h}$ before the next experiment.

\section{Radiological study}

Micro-CT (SkyScan-1276) was used to record the microstructure of the metaphyses of the femur shaft at $5 \mu \mathrm{m}$ per layer, and the X-ray parameters were set at a voltage of $55 \mathrm{kV}$ with a current of $72 \mu \mathrm{A}$ together with a 0.4-degree rotational step. The trabecular region of 17 -week-old mice was approximately $0.5 \mathrm{~mm}$ from the growth plate level in the direction of the metaphysis, and extended from this position for an additional $2 \mathrm{~mm}$. The trabecular regions of 8-week-old and 9-week-old mice were approximately $1 \mathrm{~mm}$ from the growth plate level in the direction of the metaphysis, and extended from this position for an additional $2 \mathrm{~mm}$. The cortical region of 17 -week-old mice was approximately $6 \mathrm{~mm}$ from the growth plate level in the direction of the metaphysis, and extended from this position for an additional $1 \mathrm{~mm}$. The cortical regions of 8 week-old and 9-week-old mice were approximately $4 \mathrm{~mm}$ from the growth plate level in the direction of the metaphysis, and extended from this position for an additional $1 \mathrm{~mm}$. The data were reconstructed by NRecon1.7.3.1 with a pixel size of $5.0 \mu \mathrm{m}$ and angular step of 0.4 degree. The trabecular bone mineral density (BMD), trabecular bone volume fraction (BV/TV), trabecular number (Tb. N), trabecular thickness (Tb. Th), trabecular separation (Tb. SP), trabecular pattern factor (Tb.Pf), structure model index (SMI), cortical bone mineral density (BMD), cortical bone volume fraction (BV/TV), cortical number (Ct. N), cortical thickness (Ct. Th), and cortical porosity (Ct. Porosity) were recorded. Details about the materials and reagents involved in this paper are shown in Supplementary Table 3.
Fig. 2 Melatonin prevented HGinduced cellular senescence via MT1/MT2-Sirt1 pathway. MC3T3-E1 cells were cultured by HG for 7 days then transfected with plasmid for MT1 $(\mathbf{A}, \mathbf{D})$ or MT2 (B, E) and siRNA for Sirt1 (C, F) by lipo2000 respectively, followed by $1 \mu \mathrm{m}$ melatonin or not for $48 \mathrm{~h}$. A-C Total proteins were extracted with RIPA from transfected cells. A, B Total proteins were blotted with anti-p16, anti- $\gamma$-H2AX, anti-p21, anti-MT1 or anti-MT2, anti-p53, anti-Sirt1, anti-ATM, and anti-beta actin antibodies. C Total proteins were blotted with anti-p16, anti- $\gamma$ H2AX, anti-p21, anti-p53, antiSirt1, and anti-beta actin antibodies. D-F Transfected cells were stained with DCFH-DA (green), $\gamma$-H2AX (red), and SA- $\beta$-Gal (blue). Scale bars $=50 \mu \mathrm{m}, 100$ $\mu \mathrm{m}, 200 \mathrm{px}$.
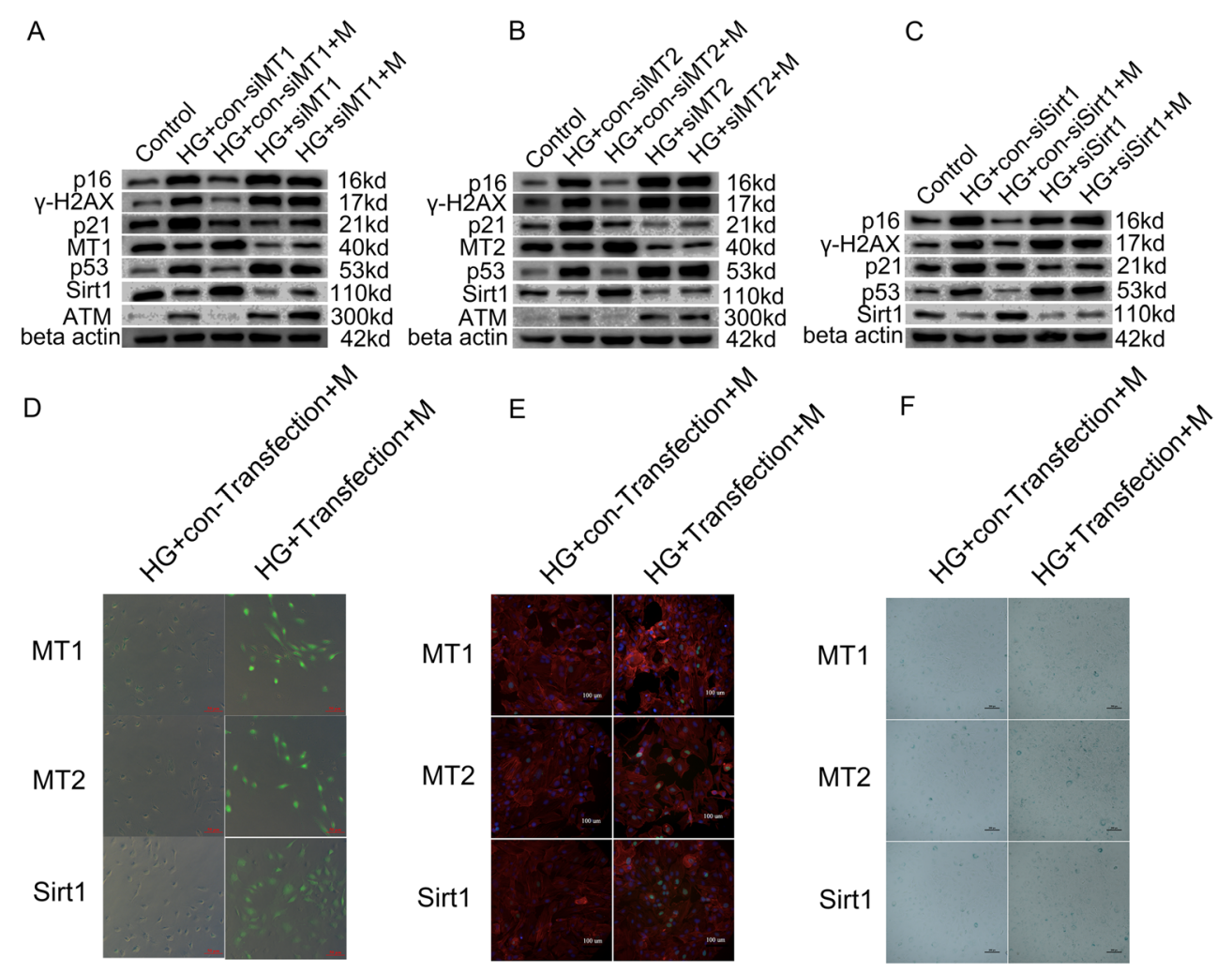
A

Cell Cycle analysis

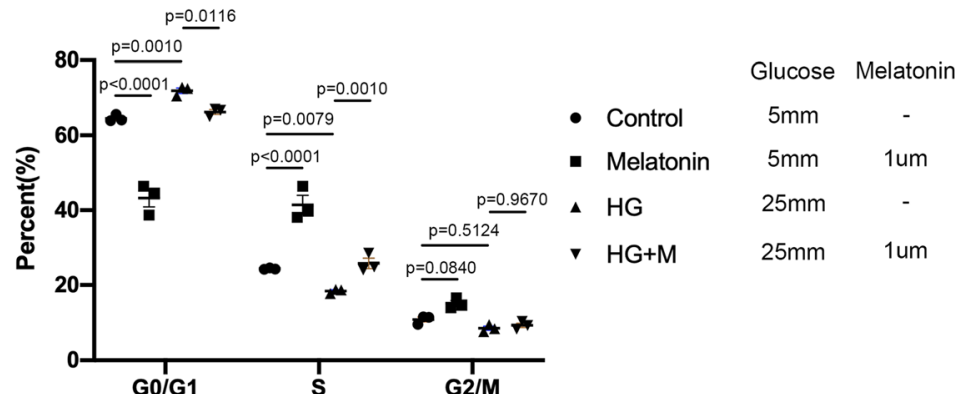

C

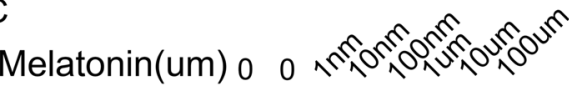

Glucose(mm) 525252525252525

Cdk2 =-ーーーーーー $33 \mathrm{kd}$

Cdk4 -

cyclinD1

Bmi1 - - - - $37 \mathrm{kd}$

MT1 - - - - - 40kd

MT2 -ーーーーー- $40 \mathrm{kd}$

Rnf2 --ー-ー-ー- 40kd

Ezh2 - - - - - 93kd

Suz12 - - - - $-95 \mathrm{kd}$

Sirt1 - - - - $110 \mathrm{kd}$

beta actin

F

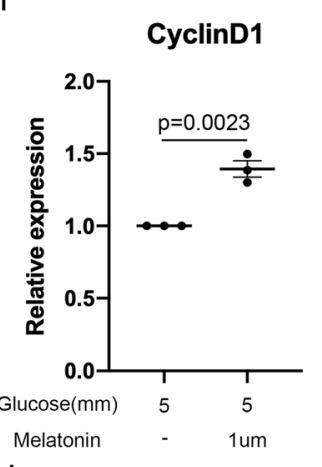

J

G
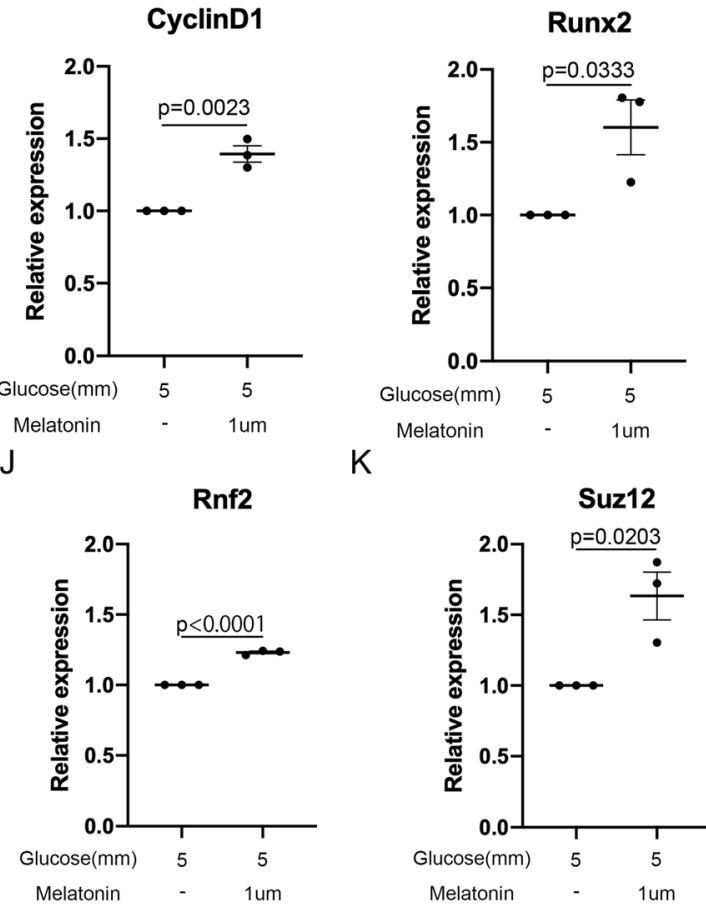

K

Suz12

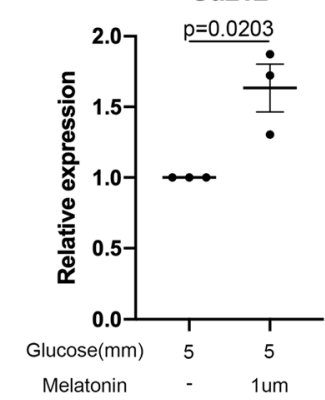

D
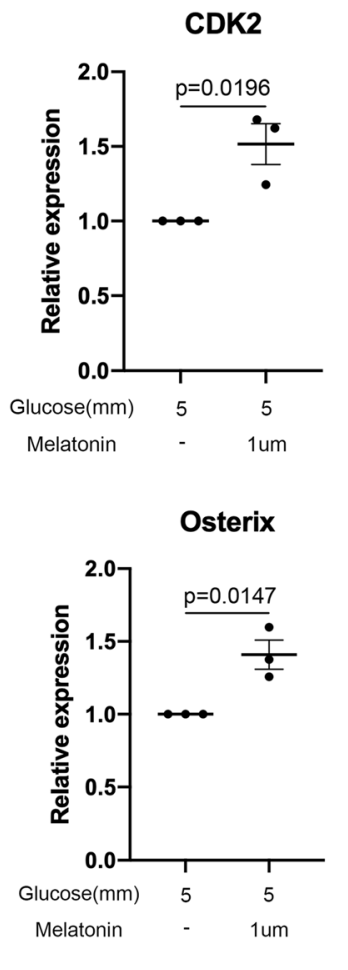

EZH2

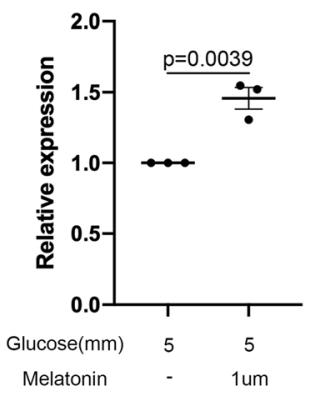

B

Melatonin

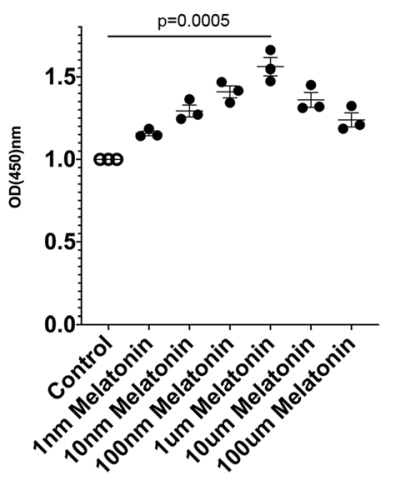

E

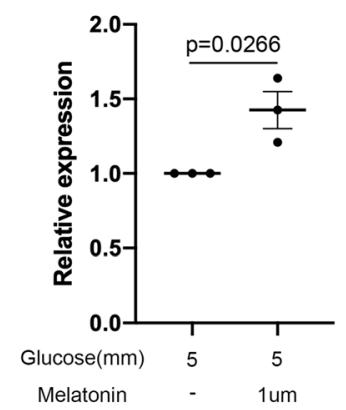

Bmi1

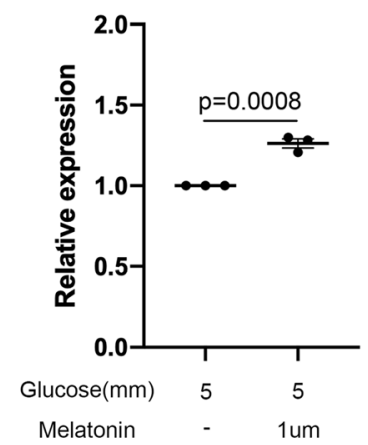

\section{Statistics}

All the data presented as the mean \pm SEM were from experiments performed at least three times with biological and

technical replicates. The significant differences between groups in all cases were analyzed by two-tailed, unpaired Student's t test with GraphPad Prism 8.2.0. P values $<0.05$ were considered statistically significant. 
Fig. 3 Melatonin abrogated HG-induced cell cycle arrest and promoted cell cycle propagation. A MC3T3-E1 cells were cultured with normal medium or HG condition for 7 days followed by melatonin or not for $48 \mathrm{~h}$. The cell cycle analysis was carried out by the Beckman instrument. Results were analyzed by Flow Jo 10 (BD, America) software. B MC3T3-E1 cells were cultured with low glucose medium $(5 \mathrm{~mm})$ for 7 days followed by different concentrations of melatonin $(0,1 \mathrm{~nm}, 10 \mathrm{~nm}$, $100 \mu \mathrm{m}, 1 \mu \mathrm{m}, 10 \mu \mathrm{m}, 100 \mu \mathrm{m})$ for $48 \mathrm{~h}$. CCK8 assay was delivered to measure the proliferation of MC3T3-E1 cells under different conditions. MC3T3-E1 cells were cultured with normal or HG medium for 7 days followed by different concentrations of melatonin $(0,1 \mathrm{~nm}, 10 \mathrm{~nm}, 100$ $\mathrm{nm}, 1 \mu \mathrm{m}, 10 \mu \mathrm{m}, 100 \mu \mathrm{m}$ ) for $48 \mathrm{~h}$. C Total proteins were extracted and blotted by anti-CDK2, anti-CDK4, anti-cyclinD1, anti-Bmi1, anti-MT1, anti-MT2, anti-Rnf2, anti-Ezh2, anti-Suz12, anti-Sirt1, and anti-beta actin antibodies. D-L MC3T3-E1 cells were cultured with HG medium for 7 days followed by $1 \mu \mathrm{m}$ melatonin for $48 \mathrm{~h}$. The relative mRNA expression levels of CDK2 ( $\mathrm{p}=0.0196)$, CDK4 ( $\mathrm{p}=0.0266)$, CyclinD1 ( $\mathrm{p}=$ $0.0023)$, Runx2 ( $\mathrm{p}=0.0333)$, Osterix $(\mathrm{p}=0.0147)$, Bmil $(\mathrm{p}=0.0008)$, Rnf2 (p < 0.0001), SUZ12 ( $=0.0203)$, and EZH2 ( $=0.0039)$ were normalized to beta actin. Data of $\mathbf{A}-\mathbf{B}$ and $\mathbf{D}-\mathbf{L}$ were presented with mean \pm SEM and analyzed by Graph pad Prism 8.2.0 (San Diego, CA, USA) with two-tailed unpaired Student's t test. Statistical significance was determined as $\mathrm{p}<0.05$

\section{Result}

\section{Melatonin alleviated HG-induced senescence of MC3T3-E1 cells}

HG inhibited the proliferation of MC3T3-E1 cells in a dosedependent manner, especially at $25 \mathrm{mmol} / \mathrm{l}(\mathrm{p}<0.0001$, Fig. 1A). This phenomenon was prevented by $1 \mu \mathrm{mol} / 1$ melatonin $(p=0.0024)$ (Fig. 1B). HG increased the expression of $16, \gamma$ H2AX, p21, p53, and ATM (Fig. 1C). Melatonin reduced the overexpression of p16, $\gamma$-H2AX, p21, p53, and ATM (Fig. 1D). Additionally, HG induced ROS overproduction and the senescence of MC3T3-E1 cells in a dose-dependent manner, especially at a dose of $25 \mathrm{mmol} / \mathrm{l}$ (Fig. 1E, F). However, melatonin alleviated the higher ROS levels and DNA damage induced by HG (Fig. 1G, H). The results of SA- $\beta$-Gal staining indicated that melatonin significantly alleviated HG-induced cellular senescence (Fig. 1I). Melatonin alleviated the HGinduced mRNA levels of p16 $(\mathrm{p}=0.0004), \mathrm{p} 21(\mathrm{p}=$ $0.0018)$, IL-1 $\beta(p=0.0284)$, and TNF- $\alpha(p=0.018)$ (Fig. $1 \mathrm{~J}-\mathrm{M})$. The mRNA level of Sirt1 was reduced under HG conditions $(p<0.0001)$, while melatonin prevented this reduction $(\mathrm{p}=0.0105)($ Fig. $1 \mathrm{~N})$.
A
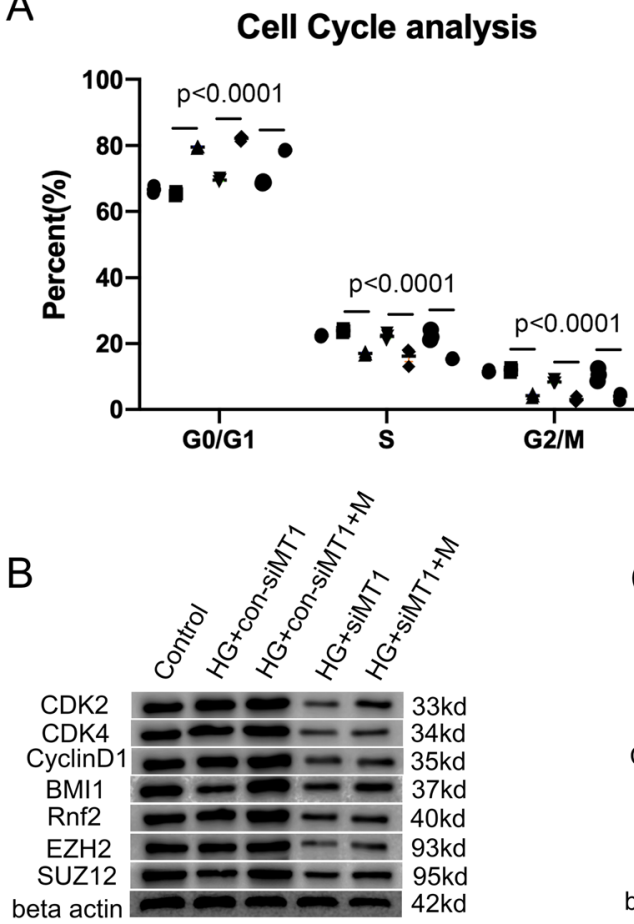

Fig. 4 Melatonin abrogated HG-induced cell cycle arrest and promoted cell proliferation via MT1/MT2 pathway. A MC3T3-E1 cells were cultured by HG for 7 days then transfected with plasmid for MT1 and MT2, siRNA for Sirt 1 by lipo2000 respectively, followed by $1 \mu \mathrm{m}$ melatonin or not for $48 \mathrm{~h}$. The cell cycle analysis was carried out by Beckman instrument. Results were analyzed by Flow Jo 10 (BD, America) software. BC MC3T3-E1 cells were cultured by HG for 7 days then transfected with

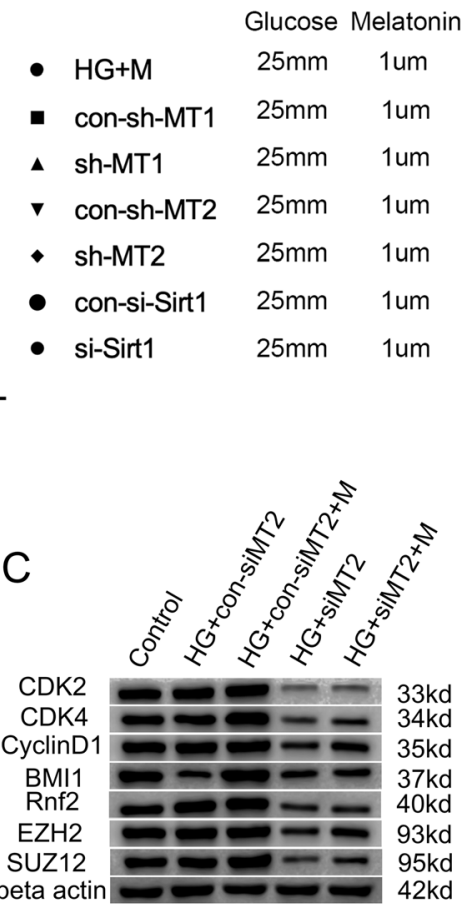

plasmid for MT1 or MT2 by lipo2000 respectively, followed by $1 \mu \mathrm{m}$ melatonin or not for $48 \mathrm{~h}$. Total proteins were extracted and blotted by anti-CDK2, anti-CDK4, anti-cyclinD1, anti-Bmi1, anti-Rnf2, anti-Ezh2, anti-Suz12, and anti-beta actin antibodies. Data of $\mathbf{A}$ were presented with mean \pm SEM and analyzed by Graph Pad Prism 8.2.0 (San Diego, CA, USA) with two-tailed unpaired Student's t test. Statistical significance was determined as $\mathrm{p}<0.05$ 


\section{Melatonin prevented HG-induced cellular senescence via the MT1/MT2-Sirt1 pathway}

MC3T3-E1 cells were cultured under HG conditions for 1 week before the knockdown of MT1 or MT2. Then, the cells were cultured with or without melatonin (1 $\mu \mathrm{mol} / \mathrm{l})$ for $48 \mathrm{~h}$ before harvest. Western blot analysis indicated that knockdown of MT1 and MT2 was successful. After knocking down of MT1 or MT2, melatonin failed to reduce the protein levels of $\gamma-\mathrm{H} 2 \mathrm{AX}, \mathrm{p} 16$, p53, and ATM induced by HG (Fig. 2A, B). However, the protein expression level of $\mathrm{p} 21$ was downregulated after MT1 or MT2 was knocked down (Fig. 2A, B). The anti-DNA damage, anti-ROS, and anti-senescence effects of melatonin almost disappeared after MT1 or MT2 was knocked down (Fig. 2D-F). Knockdown of MT1 or MT2 significantly reduced the protein level of Sirt1, while melatonin failed to restore this effect (Fig. 1A, B). Sirt1 knockdown was induced via siRNA interference (Supplementary Table 4). Western blot analysis indicated that knockdown of Sirt1 was successful. Melatonin failed to reduce the protein levels of $\gamma$-H2AX, p16, p21, and p53 induced by HG after Sirt1 was knocked down (Fig. 2C). Additionally, the anti-DNA damage, anti-ROS, and anti-senescence effects of melatonin were reduced after Sirt1 was knocked down (Fig. 2D-F). Collectively, melatonin prevented $\mathrm{HG}$ condition-induced senescence of MC3T3-E1 cells via the MT1/MT2-Sirt1 pathway.

\section{Melatonin abrogated HG-induced cell cycle arrest and promoted cell cycle progression}

HG increased the percentage of MC3T3-E1 cells in the G1 phase $(\mathrm{p}=0.001)$ and reduced the percentage of cells in the $\mathrm{S}$ phase $(\mathrm{p}=0.0079)$. Melatonin promoted cell cycle progression by increasing the percentage of cells in the $\mathrm{S}$ phase and abrogated HG-induced cell cycle arrest (Fig. 3A). Melatonin promoted cell proliferation in a dose-dependent manner, especially at a dose of $1 \mu \mathrm{mol} / 1$ ( $p=0.0005)$ (Fig. 3B). Melatonin increased the protein levels of Cdk2, Cdk4, CyclinD1, MT1, MT2, Bmi1, Rnf2, Ezh2, Suz12, and Sirt1 under HG conditions (Fig. 3C). The mRNA levels of CDK2 ( $p=$ 0.0196), CDK4 ( $\mathrm{p}=0.0266)$, CyclinD1 $(\mathrm{p}=0.0023)$, Runx2 ( $\mathrm{p}=0.0333)$, Osterix $(\mathrm{p}=0.0147)$, Bmil $(\mathrm{p}=$ $0.0008), \operatorname{Rnf} 2(\mathrm{p}<0.0001), \operatorname{SUZ12}(\mathrm{p}=0.0203)$, and EZH2 ( $p=0.0039)$ were increased in MC3T3-E1 cells after melatonin treatment (Fig. 3D-L). Collectively, these results indicated that melatonin abrogated HGinduced cell cycle arrest and promoted cell cycle progression.

\section{Melatonin promoted the expression of cell cycle- related genes via the MT1/MT2 pathway}

MC3T3-E1 cells were cultured with HG for 1 week before knockdown of MT1 or MT2. The knockdown cells were then cultured with melatonin $(1 \mu \mathrm{mol} / \mathrm{l})$ for $48 \mathrm{~h}$ before being harvested. Melatonin failed to prevent the G1-phase arrest induced by HG after MT1 ( $p<0.0001)$, MT2 ( $<<0.0001)$, or Sirt1 ( $\mathrm{p}<0.0001)$ was knocked down (Fig. 4A). Knockdown of MT1 or MT2 reduced the protein levels of CDK2, CDK4, CyclinD1, Bmi1, Rnf2, SUZ12, and EZH2, whereas melatonin failed to increase the expression of these proteins (Fig. 4B, C). Collectively, these results indicated that melatonin promotes the expression of cell cycle-related genes and promotes the progression of the cell cycle via the MT1 and MT2 pathways.

\section{Melatonin alleviated bone loss and senescence in T1D mice}

The mice treated with a single-bolus intraperitoneal injection of STZ showed diabetic phenotype (Fig. 5A-D). The protein levels of $\gamma-\mathrm{H} 2 \mathrm{AX}, \mathrm{p} 16, \mathrm{p} 21$, and p53 in the femurs of T1D mice were significantly increased, whereas melatonin administration reduced these levels. In addition, melatonin significantly increased the protein levels of Bcl2, Cdk2, Cdk4, CyclinD1, MT1, MT2, Bmi1, Rnf2, Runx2, Ezh2, Suz12, and Sirt1 in T1D mice (Fig. 5E). The micro-CT results indicated that melatonin prevented bone loss in T1D mice and increased the bone mass of control mice (Fig. 5F, G). The results of trabecular BMD, BV/TV, Tb. N, Tb. Sp cortical $\mathrm{BMD}$, and porosity indicated that the trabecular and cortical bone loss happens in the early stage of diabetes (Fig. 6A-C, E). The results of trabecular BMD, BV/TV, Tb. N, Tb. SP, Tb. $\mathrm{Pf}$, and SMI indicated that the trabecular bone loss induced by T1D was prevented by melatonin administration (Fig. 6A-C, E-G). Additionally, administration of melatonin increased the trabecular bone mass of sham mice (Fig. 6A-C, E-G). The results of cortical BMD and porosity indicated that the cortical bone loss and porosity induced by T1D were prevented by melatonin administration (Fig. 6H, L). Additionally, melatonin showed beneficial effects on cortical BMD and porosity of sham mice (Fig. 6H, L). However, the trabecular Tb. Th, cortical BV/TV, Ct. N, and Ct. SP were not statistically significant (Fig. 6D, I, J, K). Collectively, results from in vivo experiments indicated that melatonin alleviated trabecular and cortical bone loss and senescence in T1D mice.

\section{Discussion}

Compared with that of control rats, the volumetric BMD of diabetic Sprague Dawley rats decreased significantly, while 
A

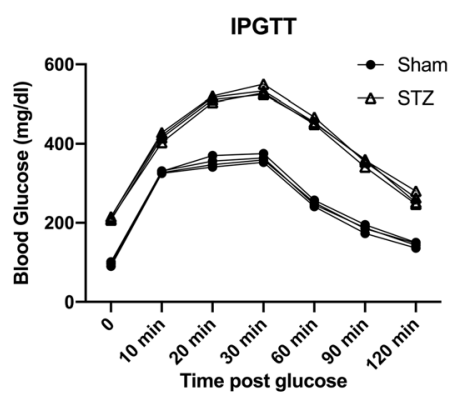

C

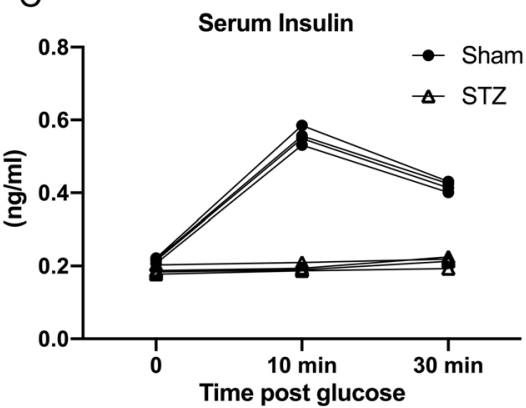

B

\section{Area under curve}

$\mathrm{p}<0.0001$

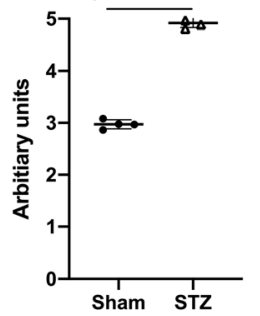

E

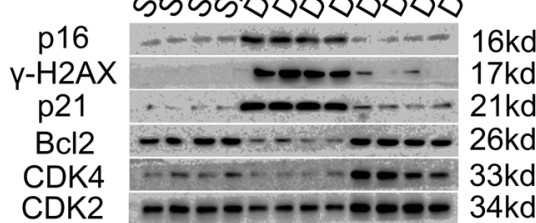

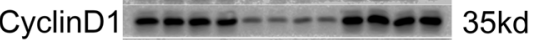

Bmi1 -0-0-0.-0-0-37kd

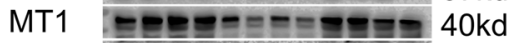

MT2 - $2-\infty-\infty \mathrm{kd}$

Rnf2 - - -

p53

Runx2 -0-0-0.--0 60kd

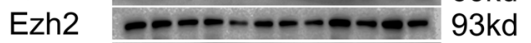

Suz12 -

Sirt1 -ーーーーーー-00-0110kd beta actin- - - $-0-0-04$ 42kd

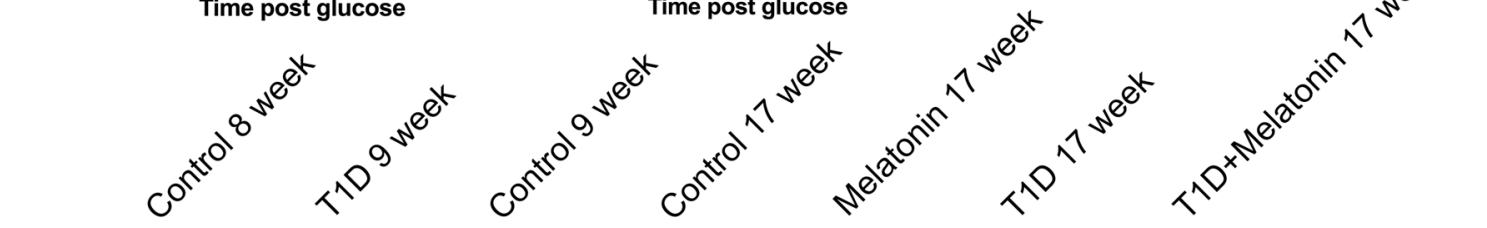

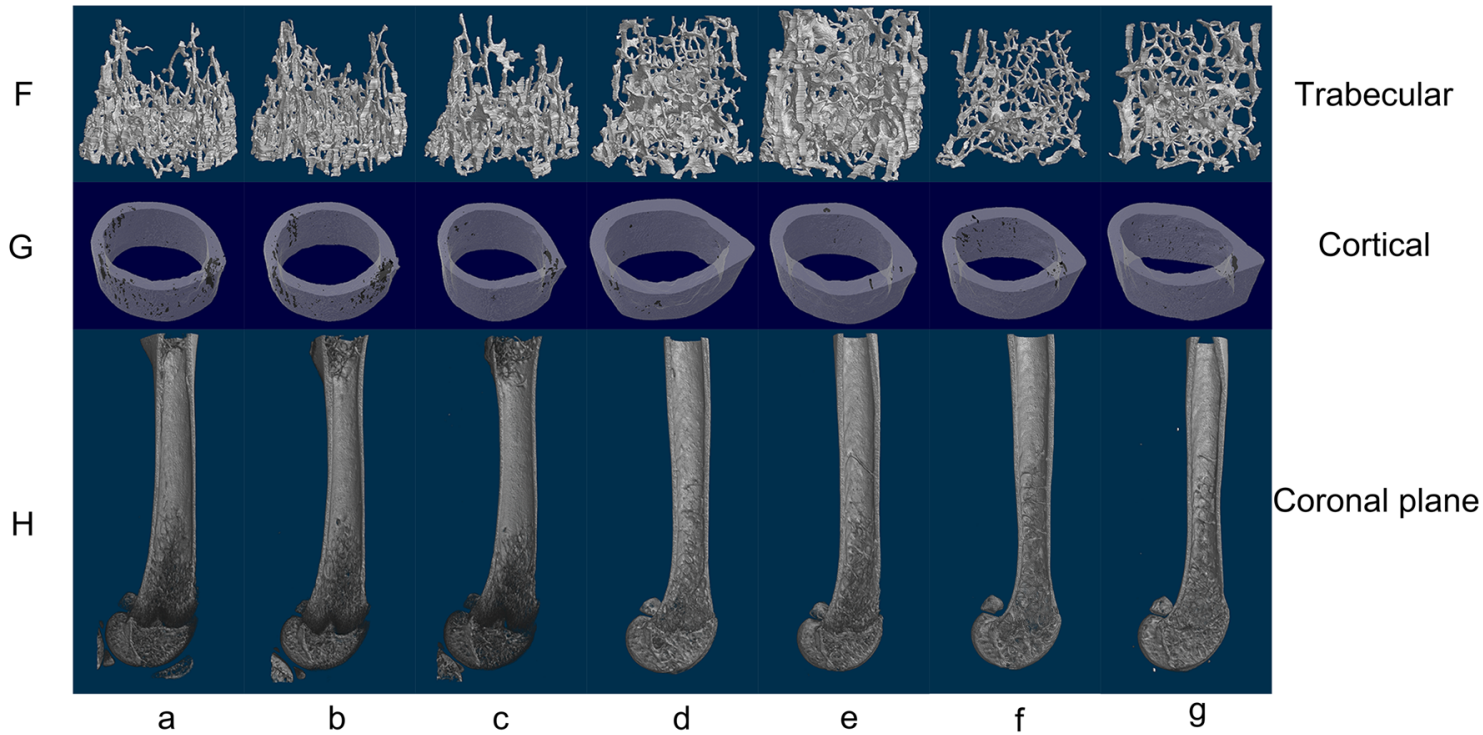

Fig. 5 Melatonin alleviated bone loss and senescence in DM1 C57BL/6 mice. A-D One week after intraperitoneal injection of STZ, C57BL/6 mice were injected with $1 \mathrm{~g} / \mathrm{kg}$ glucose after overnight fasting. A, B Blood samples were collected from the tail vein at $0,10,20,30,60,90$, and $120 \mathrm{~min}$. respectively, and blood glucose was measured by a OneTouch glucometer (Lifescan). C, D Blood samples were collected from the tail vein at 0,10 , and 30 min respectively, and blood insulin levels were measured using radioimmunoassay (Millipore). $\mathbf{E}-\mathbf{H}$ C57BL/ 6 mice were intraperitoneally injected with STZ $(160 \mathrm{mg} / \mathrm{kg})$, then treated with melatonin $(60 \mathrm{mg} / \mathrm{kg} /$ day $)$ for 2 months. E Total proteins were

extracted by Invent kit from femurs of DM1 mice and DM1 mice treated with melatonin. Total proteins were blotted with anti-p16, anti- $\gamma-\mathrm{H} 2 \mathrm{AX}$, anti-p21, anti-Bcl2, anti-CDK2, anti-CDK4, anti-cyclinD1, anti-Bmi1, anti-MT1, anti-MT2, anti-Rnf2, anti-p53, anti-Runx2, anti-Ezh2, antiSuz12, anti-Sirt1 and anti-beta actin antibodies. Data of $\mathbf{F}-\mathbf{H}$ were reconstructed by NRecon-1.7.3.1. Data of A-D were presented with mean \pm SEM and analyzed by Graph Pad Prism 8.2.0 (San Diego, CA, USA) with two-tailed unpaired Student's t test. Statistical significance was determined as $\mathrm{p}<0.05$ 


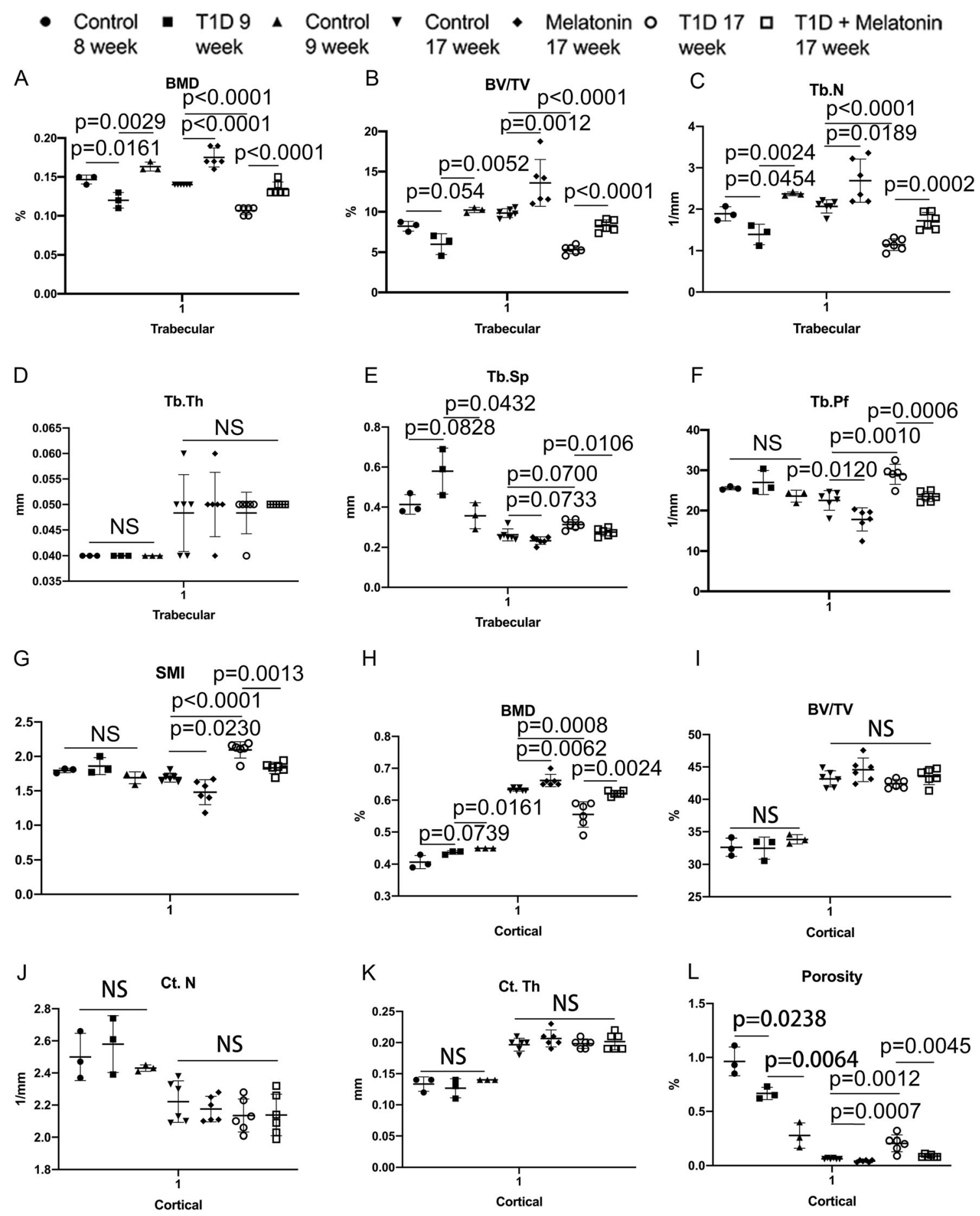

Fig. 6 A-L Quantification of trabecular bone mineral density (BMD), trabecular bone volume fraction (BV/TV), trabecular number (Tb. N), trabecular thickness $(\mathrm{Tb}$. Th), trabecular separation (Tb. SP), trabecular pattern factor (Tb.Pf), structure model index (SMI), cortical bone mineral density (BMD), cortical bone volume fraction (BV/TV), cortical number

the BV/TV of proximal tibial trabeculae decreased by $60 \%$ [15]. Additionally, diabetic F344 and Sprague Dawley rats had delayed cortical development compared with control rats [15]. Furthermore, the cortical thickness and cross-sectional area of the proximal femur were lower in T1D patients [6].
(Ct. N), cortical thickness (Ct. Th), and cortical porosity (Ct. Porosity), $n$ $\geq 3$. Data of (A-L) were presented with mean \pm SEM and analyzed by Graph pad Prism 8.2.0 (San Diego, CA, USA) with two-tailed unpaired Student's $t$ test. Statistical significance was determined as $p<0.05$

Moreover, the decrease in bone formation in T1D patients occurred in early stages of the disease, especially in patients with poor glycemic control [16]. Moreover, at the tibial shaft, after adjusting for age, BMI, and tibial length, the cortical thickness of early-onset T1D patients was less than that of 
adult-onset T1D patients [17]. Senescence has been considered one of the pathological mechanisms underlying diabetic osteoporosis [8]. T1D and HG can both lead to senescence, as previously reported $[8,18,19]$. Compared with those of nondiabetic mice, the mRNA levels of p53, p21, and p16 were significantly increased in the retina extracts of diabetic mice [18]. Immunofluorescence staining revealed that high-glucose (30 $\mathrm{mmol} / \mathrm{l}$ ) conditions significantly increased the levels of p16 and p21 [20]. Thus, targeting cellular senescence has been an anti-osteoporosis therapeutic strategy [21]. As an endocrine molecule secreted by the pineal gland, melatonin exhibits antisenescence effects $[11,22]$. To explore whether administration of melatonin can alleviate T1D-induced diabetic osteoporosis, we performed micro-CT analysis.

After melatonin administration, the amount of BMD increased [23, 24], the width and length of cortical bone formation increased [25], the trabecular number and trabecular thickness increased, and trabecular defects were reversed [26]. By activating MT2, melatonin upregulates osteogenicrelated protein expression and inhibits osteolysis-related factor expression [12]. The number and volume of trabecular bones in $\mathrm{MT}^{-1-}$ mice were significantly reduced, and the separation of trabecular bones was increased [26]. The micro-CT results indicated that melatonin prevented T1Dinduced bone loss and promoted bone formation in sham mice. To explore the anti-bone loss and osteogenesis mechanisms of melatonin, we tested the total proteins extracted from mouse femurs. In vivo experiments revealed that melatonin reduced the level of senescence-associated proteins in T1D mice and increased the level of osteogenesis-related proteins.

To explore the mechanism underlying the anti-bone loss effect of melatonin and its role in promoting bone formation, and to determine whether its anti-senescence effects play a major role in its anti-bone loss mechanisms, we performed in vitro experiments. HG culture medium was used to imitate high circulating blood glucose levels, and melatonin treatment was applied. In brief, melatonin prevented HG conditioninduced ROS overproduction, DNA damage, hypo-proliferation, and senescence of MC3T3-E1 cells. Additionally, melatonin promoted MC3T3-E1 cell proliferation and increased the levels of osteogenesis-related proteins. To further explore the anti-senescence and osteogenesis mechanisms of melatonin, the study focused on the process of senescence and the proteins or factors that participate in the regulation of senescence. There are melatonin receptors expressed in the bone. Therefore, we investigated whether the anti-senescence effects of melatonin depend on its receptors, and the potential interactions between melatonin receptors and senescenceregulating proteins.

The factors leading to senescence include telomere shortening, ROS overproduction, DNA damage, and cytokine production, and these factors are associated with the senescenceassociated secretory phenotype (SASP) [27-30]. Senescence arrest mainly occurs in the G1 phase of the cell cycle. Most of the senescence-inducing factors activate the p53-p21 and/or pRB-p16 pathway. P16 and p21 are both cyclin-dependent kinase inhibitors [29, 31]. Melatonin pretreatment prevented the dexamethasone-induced downregulation of CDK2 in progenitor cells obtained from the adult rat hippocampus [32]. We previously found that melatonin at a concentration of $1 \mathrm{mM}$ inhibited the proliferation of the hFOB 1.19 human osteoblastic cell line and downregulated cyclin D1 and CDK4 expression. Additionally, melatonin inhibited the proliferation of the hFOB 1.19 human osteoblastic cell line at high concentrations but increased proliferation at low concentrations [33]. Collectively, these results suggest that the effect of melatonin on cell cycle-related gene expression is related to drug concentration and target cells. The present work found that melatonin promotes cell cycle progression and prevents HG-induced G1 arrest in an MT1- and MT2-dependent manner. The inhibition of cyclin D1 or CDK4/6 promotes the senescence of a variety of tumor cell types [34-36]. Overexpression of CDK 4 and CDK6 delays senescence of human diploid fibroblasts [37]. It has been reported that melatonin at a concentration of $1 \mathrm{mM}$ decreased the protein levels of CDK2, CDK4, and Cyclin D1 in H1975 non-small-cell lung cancer cells, B65 neuroblastoma cells, and X02 cancer stem cells [38-40]. We found for the first time that low concentrations of melatonin increased the expression of CDK2, CDK4, and CyclinD1 through the MT1 and MT2 pathways, which may be one of the anti-senescence mechanisms of melatonin.

In proliferating cells, INK4 sites (encoding p16 and p15) are maintained in an inhibitory chromatin state by $\mathrm{PRC} 1 / 2$. It has been reported that PRC inhibits senescence and prevents bone osteoporosis [41]. As a component of PRC1, Bmil overexpression promotes osteogenic differentiation potential and inhibits cellular senescence [42]. Additionally, Bmil knockout mice presented with obvious premature senescence and osteoporosis [43]. As a component of PRC2, EZH2 plays an important role in the inhibition of key senescence-related proteins in early puberty. The absence of EZH2 leads to premature cellular senescence, low bone formation, and osteoporosis [44]. Interestingly, it has been reported that melatonin can increase the mRNA level of Bmil in C6 glioma cells [45]. For the first time, we found that melatonin increased the expression of Bmi1, Rnf2, Ezh2, and Suz12 via the MT1 and MT2 pathways, which may be one of the anti-senescence mechanisms of melatonin.

As an $\mathrm{NAD}^{+}$-dependent enzyme closely related to senescence, Sirt1 prevents glucose-induced cellular senescence of endothelial cells [46]. Additionally, Sirt1 gene knockdown increases the expression of p53 and p21 in renal adenocarcinoma cells [47]. It has been reported that melatonin inhibits the production of ROS by upregulating Sirt1 [48]. Moreover, the melatonin receptor antagonist luzindole partially 
abrogated the upregulation effect of melatonin on Sirt1 [49]. Then, we explored whether Sirt1 participated in the antisenescence effect of melatonin. Here, we found that melatonin induced anti-ROS, anti-DNA damage, and anti-senescence effects by upregulating Sirt1 via the MT1 and MT2 pathway.

Collectively, melatonin prevented senescence and bone loss of T1D mice, which may be attributed to the multiple anti-senescence effects. Further to this, melatonin promoted the bone formation of sham mice, which may be attributed to the promotion of the proliferation of preosteoblasts. The limitation of this work is that the mechanisms by which the melatonin receptors exert anti-senescence effects were based on preosteoblast MC3T3-E1 cell studies.

\section{Conclusion}

This work shows the protective effects and underlying mechanisms of melatonin on T1D-induced bone loss. Targeting senescence in the investigation of diabetic osteoporosis may lead to novel discoveries. Further study should focus on the anti-senescence and anti-osteoporosis mechanisms associated with melatonin and its receptors at the transgenic mouse level.

Supplementary Information The online version contains supplementary material available at https://doi.org/10.1007/s00198-021-06061-8.

Acknowledgements This study was supported by the Natural Science Foundation of Liao Ning, grant number 2019-BS-294, and the Construction of Clinical Medical Research Center of Orthopaedics and Sports Rehabilitation Diseases in Liaoning Province, grant number 2019416030

Data availability The data from studies that have not been the subject of previous publications are used in the submitted manuscript, and provide information on all relevant publications.

\section{Declarations}

Conflicts of interest None.

Open Access This article is licensed under a Creative Commons Attribution-NonCommercial 4.0 International License, which permits any non-commercial use, sharing, adaptation, distribution and reproduction in any medium or format, as long as you give appropriate credit to the original author(s) and the source, provide a link to the Creative Commons licence, and indicate if changes were made. The images or other third party material in this article are included in the article's Creative Commons licence, unless indicated otherwise in a credit line to the material. If material is not included in the article's Creative Commons licence and your intended use is not permitted by statutory regulation or exceeds the permitted use, you will need to obtain permission directly from the copyright holder. To view a copy of this licence, visit http:// creativecommons.org/licenses/by-nc/4.0/.

\section{References}

1. Aung M, Amin S, Gulraiz A, Gandhi FR, Pena Escobar JA, Malik $\mathrm{BH}$ (2020) The future of metformin in the prevention of diabetesrelated osteoporosis. Cureus 12(9):e10412. https://doi.org/10.7759/ cureus. 10412

2. Neglia C, Argentiero A, Chitano G, Agnello N, Ciccarese R, Vigilanza A, Pantile V, Argentiero D, Quarta R, Rivezzi M, Di Tanna GL, Di Somma C, Migliore A, Iolascon G, Gimigliano F, Distante A, Piscitelli P (2016) Diabetes and obesity as independent risk factors for osteoporosis: updated results from the ROIS/ EMEROS registry in a population of five thousand postmenopausal women living in a region characterized by heavy environmental pressure. Int J Environ Res Public Health 13(11). https://doi.org/10.3390/ijerph13111067

3. Ferrari SL, Abrahamsen B, Napoli N, Akesson K, Chandran M, Eastell R, El-Hajj Fuleihan G, Josse R, Kendler DL, Kraenzlin M, Suzuki A, Pierroz DD, Schwartz AV, Leslie WD, Bone, Diabetes Working Group of IOF (2018) Diagnosis and management of bone fragility in diabetes: an emerging challenge. Osteoporos Int 29(12): 2585-2596. https://doi.org/10.1007/s00198-018-4650-2

4. Vestergaard P (2007) Discrepancies in bone mineral density and fracture risk in patients with type 1 and type 2 diabetes-a metaanalysis. Osteoporos Int 18(4):427-444. https://doi.org/10.1007/ s00198-006-0253-4

5. Mastrandrea LD, Wactawski-Wende J, Donahue RP, Hovey KM, Clark A, Quattrin T (2008) Young women with type 1 diabetes have lower bone mineral density that persists over time. Diabetes Care 31(9):1729-1735. https://doi.org/10.2337/dc07-2426

6. Starup-Linde J, Hygum K, Harslof T, Langdahl B (2019) Type 1 diabetes and bone fragility: links and risks. Diabetes Metab Syndr Obes 12:2539-2547. https://doi.org/10.2147/DMSO.S191091

7. Portal-Núñez S, Ardura JA, Lozano D, Bolívar OH, LópezHerradón A, Gutiérrez-Rojas I, Proctor A, van der Eerden B, Schreuders-Koedam M, van Leeuwen J, Alcaraz MJ, Mulero F, de la Fuente M, Esbrit P (2016) Adverse effects of diabetes mellitus on the skeleton of aging mice. J Gerontol A Biol Sci Med Sci 71(3): 290-299. https://doi.org/10.1093/gerona/glv160

8. Li YM, Schilling T, Benisch P, Zeck S, Meissner-Weigl J, Schneider D, Limbert C, Seufert J, Kassem M, Schütze N, Jakob F, Ebert R (2007) Effects of high glucose on mesenchymal stem cell proliferation and differentiation. Biochem Biophys Res Commun 363(1):209-215. https://doi.org/10.1016/j.bbrc.2007.08. 161

9. Kim J, Piao Y, Pak YK, Chung D, Han YM, Hong JS, Jun EJ, Shim JY, Choi J, Kim CJ (2015) Umbilical cord mesenchymal stromal cells affected by gestational diabetes mellitus display premature aging and mitochondrial dysfunction. Stem Cells Dev 24(5):575586. https://doi.org/10.1089/scd.2014.0349

10. Majidinia M, Reiter RJ, Shakouri SK, Yousefi B (2018) The role of melatonin, a multitasking molecule, in retarding the processes of ageing. Ageing Res Rev 47:198-213. https://doi.org/10.1016/j.arr. 2018.07.010

11. Yang F, Yang L, Li Y, Yan G, Feng C, Liu T, Gong R, Yuan Y, Wang N, Idiiatullina E, Bikkuzin T, Pavlov V, Li Y, Dong C, Wang D, Cao Y, Han Z, Zhang L, Huang Q, Ding F, Bi Z, Cai B (2017) Melatonin protects bone marrow mesenchymal stem cells against iron overload-induced aberrant differentiation and senescence. J Pineal Res 63(3). https://doi.org/10.1111/jpi.12422

12. Li T, Jiang S, Lu C, Yang W, Yang Z, Hu W, Xin Z, Yang Y (2019) Melatonin: another avenue for treating osteoporosis? J Pineal Res 66(2):e12548. https://doi.org/10.1111/jpi.12548

13. Egermann M, Gerhardt C, Barth A, Maestroni GJ, Schneider E, Alini M (2011) Pinealectomy affects bone mineral density and 
structure-an experimental study in sheep. BMC Musculoskelet Disord 12:271. https://doi.org/10.1186/1471-2474-12-271

14. Amstrup AK, Sikjaer T, Heickendorff L, Mosekilde L, Rejnmark L (2015) Melatonin improves bone mineral density at the femoral neck in postmenopausal women with osteopenia: a randomized controlled trial. J Pineal Res 59(2):221-229. https://doi.org/10. 1111/jpi.12252

15. Silva MJ, Brodt MD, Lynch MA, McKenzie JA, Tanouye KM, Nyman JS, Wang X (2009) Type 1 diabetes in young rats leads to progressive trabecular bone loss, cessation of cortical bone growth, and diminished whole bone strength and fatigue life. J Bone Miner Res 24(9):1618-1627. https://doi.org/10.1359/jbmr.090316

16. Weber DR, Gordon RJ, Kelley JC, Leonard MB, Willi SM, HatchStein J, Kelly A, Kosacci O, Kucheruk O, Kaafarani M, Zemel BS (2019) Poor glycemic control is associated with impaired bone accrual in the year following a diagnosis of type 1 diabetes. J Clin Endocrinol Metab 104(10):4511-4520. https://doi.org/10.1210/jc. 2019-00035

17. Shah VN, Joshee P, Sippl R, Pyle L, Vigers T, Carpenter RD, Kohrt W, Snell-Bergeon JK (2019) Type 1 diabetes onset at young age is associated with compromised bone quality. Bone 123:260-264. https://doi.org/10.1016/j.bone.2019.03.039

18. Shosha E, Xu Z, Narayanan SP, Lemtalsi T, Fouda AY, Rojas M, Xing J, Fulton D, Caldwell RW, Caldwell RB (2018) Mechanisms of diabetes-induced endothelial cell senescence: role of arginase 1. Int J Mol Sci 19(4). https://doi.org/10.3390/ijms19041215

19. Wu L, Chen Y, Wang CY, Tang YY, Huang HL, Kang X, Li X, Xie YR, Tang XQ (2019) Hydrogen sulfide inhibits high glucoseinduced neuronal senescence by improving autophagic flux via upregulation of SIRT1. Front Mol Neurosci 12:194. https://doi.org/ 10.3389/fnmol.2019.00194

20. Zhang P, Wang Q, Nie L, Zhu R, Zhou X, Zhao P, Ji N, Liang X, Ding Y, Yuan Q, Wang Q (2019) Hyperglycemia-induced inflamm-aging accelerates gingival senescence via NLRC4 phosphorylation. J Biol Chem 294(49):18807-18819. https://doi.org/10. 1074/jbc.RA119.010648

21. Khosla S, Farr JN, Kirkland JL (2018) Inhibiting cellular senescence: a new therapeutic paradigm for age-related osteoporosis. J Clin Endocrinol Metab 103(4):1282-1290. https://doi.org/10.1210/ jc.2017-02694

22. Hardeland R (2019) Aging, melatonin, and the pro- and antiinflammatory networks. Int J Mol Sci 20(5). https://doi.org/10. 3390/ijms20051223

23. Koyama H, et al. (2002) Melatonin at pharmacologic doses increases bone mass by suppressing resorption through downregulation of the RANKL-mediated osteoclast formation and activation. J Bone Miner Res 17(7):1219-1229

24. Calvo-Guirado JL, Ramirez-Fernandez MP, Gomez-Moreno G, Mate-Sanchez JE, Delgado-Ruiz R, Guardia J, Lopez-Mari L, Barone A, Ortiz-Ruiz AJ, Martinez-Gonzalez JM, Bravo LA (2010) Melatonin stimulates the growth of new bone around implants in the tibia of rabbits. J Pineal Res 49(4):356-363. https://doi. org/10.1111/j.1600-079X.2010.00801.X

25. Satomura K, Tobiume S, Tokuyama R, Yamasaki Y, Kudoh K, Maeda E, Nagayama M (2007) Melatonin at pharmacological doses enhances human osteoblastic differentiation in vitro and promotes mouse cortical bone formation in vivo. J Pineal Res 42(3):231-239. https://doi.org/10.1111/j.1600-079X.2006.00410.x

26. Sharan K, Lewis K, Furukawa T, Yadav VK (2017) Regulation of bone mass through pineal-derived melatonin-MT2 receptor pathway. J Pineal Res 63(2). https://doi.org/10.1111/jpi.12423

27. Acosta JC, Banito A, Wuestefeld T, Georgilis A, Janich P, Morton JP, Athineos D, Kang TW, Lasitschka F, Andrulis M, Pascual G, Morris KJ, Khan S, Jin H, Dharmalingam G, Snijders AP, Carroll T, Capper D, Pritchard C, Inman GJ, Longerich T, Sansom OJ, Benitah SA, Zender L, Gil J (2013) A complex secretory program orchestrated by the inflammasome controls paracrine senescence. Nat Cell Biol 15(8):978-990. https://doi.org/10.1038/ncb2784

28. Campisi J (2013) Aging, cellular senescence, and cancer. Annu Rev Physiol 75:685-705. https://doi.org/10.1146/annurev-physiol$030212-183653$

29. Kuilman T, Michaloglou C, Mooi WJ, Peeper DS (2010) The essence of senescence. Genes Dev 24(22):2463-2479. https://doi.org/ 10.1101/gad.1971610

30. Ritschka B, Storer M, Mas A, Heinzmann F, Ortells MC, Morton JP, Sansom OJ, Zender L, Keyes WM (2017) The senescenceassociated secretory phenotype induces cellular plasticity and tissue regeneration. Genes Dev 31(2):172-183. https://doi.org/10.1101/ $\operatorname{gad} .290635 .116$

31. Narita M, Nũnez S, Heard E, Narita M, Lin AW, Hearn SA, Spector DL, Hannon GJ, Lowe SW (2003) Rb-mediated heterochromatin formation and silencing of E2F target genes during cellular senescence. Cell 113(6):703-716. https://doi.org/10.1016/s00928674(03)00401-x

32. Ekthuwapranee K, Sotthibundhu A, Tocharus C, Govitrapong P (2015) Melatonin ameliorates dexamethasone-induced inhibitory effects on the proliferation of cultured progenitor cells obtained from adult rat hippocampus. J Steroid Biochem Mol Biol 145:3848. https://doi.org/10.1016/j.jsbmb.2014.10.003

33. Liu L, Zhu Y, Xu Y, Reiter RJ (2011) Melatonin delays cell proliferation by inducing $\mathrm{G} 1$ and $\mathrm{G} 2$ /M phase arrest in a human osteoblastic cell line hFOB 1.19. J Pineal Res 50(2):222-231. https:// doi.org/10.1111/j.1600-079X.2010.00832.x

34. Laphanuwat P, Likasitwatanakul P, Sittithumcharee G, Thaphaengphan A, Chomanee N, Suppramote O, Ketaroonrut N, Charngkaew K, Lam EW, Okada S, Panich U, Sampattavanich S, Jirawatnotai S (2018) Cyclin D1 depletion interferes with oxidative balance and promotes cancer cell senescence. J Cell Sci 131(12). https://doi.org/10.1242/jcs.214726

35. Valenzuela CA, Vargas L, Martinez V, Bravo S, Brown NE (2017) Palbociclib-induced autophagy and senescence in gastric cancer cells. Exp Cell Res 360(2):390-396. https://doi.org/10.1016/j. yexcr.2017.09.031

36. Acevedo M, Vernier M, Mignacca L, Lessard F, Huot G, Moiseeva O, Bourdeau V, Ferbeyre G (2016) A CDK4/6-dependent epigenetic mechanism protects cancer cells from PML-induced senescence. Cancer Res 76(11):3252-3264. https://doi.org/10.1158/ 0008-5472.CAN-15-2347

37. Ruas M, Gregory F, Jones R, Poolman R, Starborg M, Rowe J, Brookes S, Peters G (2007) CDK4 and CDK6 delay senescence by kinase-dependent and p16INK4a-independent mechanisms. Mol Cell Biol 27(12):4273-4282. https://doi.org/10.1128/MCB. 02286-06

38. Yun M, Kim EO, Lee D, Kim JH, Kim J, Lee H, Lee J, Kim SH (2014) Melatonin sensitizes H1975 non-small-cell lung cancer cells harboring a T790M-targeted epidermal growth factor receptor mutation to the tyrosine kinase inhibitor gefitinib. Cell Physiol Biochem 34(3):865-872. https://doi.org/10.1159/000366305

39. Pizarro JG, Yeste-Velasco M, Esparza JL, Verdaguer E, Pallas M, Camins A, Folch J (2008) The antiproliferative activity of melatonin in B65 rat dopaminergic neuroblastoma cells is related to the downregulation of cell cycle-related genes. J Pineal Res 45(1):816. https://doi.org/10.1111/j.1600-079X.2007.00548.x

40. Lee H, Lee HJ, Jung JH, Shin EA, Kim SH (2018) Melatonin disturbs SUMOylation-mediated crosstalk between c-Myc and nestin via MT1 activation and promotes the sensitivity of paclitaxel in brain cancer stem cells. J Pineal Res 65(2):e12496. https://doi. org/10.1111/jpi.12496

41. Rayess H, Wang MB, Srivatsan ES (2012) Cellular senescence and tumor suppressor gene p16. Int J Cancer 130(8):1715-1725. https:// doi.org/10.1002/ijc.27316 
42. Sun H, Qiao W, Cui M, Yang C, Wang R, Goltzman D, Jin J, Miao D (2019) The polycomb protein Bmil plays a crucial role in the prevention of $1,25(\mathrm{OH}) 2 \mathrm{D}$ deficiency-induced bone loss. J Bone Miner Res. https://doi.org/10.1002/jbmr.3921

43. Xie C, Jin J, Lv X, Tao J, Wang R, Miao D (2015) Anti-aging effect of transplanted amniotic membrane mesenchymal stem cells in a premature aging model of Bmi-1 deficiency. Sci Rep 5:13975. https://doi.org/10.1038/srep13975

44. Li C, Chai Y, Wang L, Gao B, Chen H, Gao P, Zhou FQ, Luo X, Crane JL, Yu B, Cao X, Wan M (2017) Programmed cell senescence in skeleton during late puberty. Nat Commun 8(1):1312. https://doi.org/10.1038/s41467-017-01509-0

45. Qu J, Rizak JD, Li X, Li J, Ma Y (2013) Melatonin treatment increases the transcription of cell proliferation-related genes prior to inducing cell death in C6 glioma cells in vitro. Oncol Lett 6(2): 347-352. https://doi.org/10.3892/ol.2013.1413

46. Liu J, Chen S, Biswas S, Nagrani N, Chu Y, Chakrabarti S, Feng B (2020) Glucose-induced oxidative stress and accelerated aging in endothelial cells are mediated by the depletion of mitochondrial SIRTs. Phys Rep 8(3):e14331. https://doi.org/10.14814/phy2. 14331
47. Fujino T, Yokokawa R, Oshima T, Hayakawa M (2018) SIRT1 knockdown up-regulates p53 and p21/Cip1 expression in renal adenocarcinoma cells but not in normal renal-derived cells in a deacetylase-independent manner. J Toxicol Sci 43(12):711-715. https://doi.org/10.2131/jts.43.711

48. Li B, He X, Zhuang M, Niu B, Wu C, Mu H, Tang F, Cui Y, Liu W, Zhao B, Peng S, Li G, Hua J (2018) Melatonin ameliorates busulfan-induced spermatogonial stem cell oxidative apoptosis in mouse testes. Antioxid Redox Signal 28(5):385-400. https://doi. org/10.1089/ars.2016.6792

49. Guo P, Pi H, Xu S, Zhang L, Li Y, Li M, Cao Z, Tian L, Xie J, Li R, He M, Lu Y, Liu C, Duan W, Yu Z, Zhou Z (2014) Melatonin improves mitochondrial function by promoting MT1/SIRT1/PGC1 alpha-dependent mitochondrial biogenesis in cadmium-induced hepatotoxicity in vitro. Toxicol Sci 142(1):182-195. https://doi.org/ 10.1093/toxsci/kfu164

Publisher's note Springer Nature remains neutral with regard to jurisdictional claims in published maps and institutional affiliations. 